\title{
Histopathological study of lesions of female genital tract in rural Maharashtra
}

\author{
Anand .S .Patil ${ }^{1}$, Rahul M. Jadhav ${ }^{2, *}$, Piyush Narkhede ${ }^{3}$ \\ ${ }^{\mathbf{1}}$ Associate Professor, ${ }^{\mathbf{2}, 3}$ Assistant Professor, Dept. of Pathology, IIMS\&R Medical College and Hospital, Badnapur, Maharashtra, \\ India
}

*Corresponding Author:

Email: rahulmankura@gmail.com

\begin{abstract}
Objective: There are various lesions found in female genital tract from cervix to uterus to ovary. Although leiomyoma is the commonest lesion in female genital tract, lesions from cervix, fallopian tube and ovary are clinically important. Our objective is to analyze the various lesions in female genital tract, to study the incidence of various lesions and their interrelation.

Materials and Methods: A 1 year retrospective study conducted in the Dept. of Pathology IIMS \& R Medical College, where in 140 specimens of female genital tract (uterus, fallopian tube and ovary) were subjected to histopathological examination and relevant clinical data was analyzed.

Results: Most of the patients presented with abnormal uterine bleeding (50\%). Out of 125 hysterectomy cases, 84 had uterine pathology $(67.2 \%)$ which included leiomyoma and adenomyosis. The pyosalpinx was leading tubal pathology (15.8\%) while simple serous cysts form majority of ovarian pathology $(26.3 \%)$.

Conclusion: Though hysterectomy is a routine procedure in the management of uterine leiomyoma, occasional cases of tumor or infective pathology may be missed. The histopathological evaluation of ovarian and tubal lesions is also important for subsequent management. Therefore histopathology is mandatory for confirmed diagnosis and hence for ensuring optimal management.
\end{abstract}

Keywords: Leiomyomas, Hysterectomy.

\section{Introduction}

Hysterectomy is one of the commonest gynecological operation in pre and post-menopausal women in entire world. ${ }^{1}$ It is indicated for most of benign gynecological lesions and dysfunctional uterine bleeding. ${ }^{2}$ The leiomyoma are commonly seen benign uterine neoplasms in women of child bearing age group accounting for 5-20\%. ${ }^{3-5}$ Leiomyoma need hormonal milieu for their growth and maintenance as proved by the molecular studies that leiomyoma shows more estrogen receptors than normal myometrium..$^{5-7}$ These tumors are usually asymptomatic, however depending on their size, location and hormonal effects, the clinical symptoms vary. The commonest clinical manifestations include menorrhagia, dysmenorrhoea, pain in abdomen, mass in abdomen and mass effects. ${ }^{8}$ The symptomatic leiomyoma need priority attention either by myomectomy in younger women desirous of retaining the childbearing function or by hysterectomy..$^{9,10}$

Dysfunctional uterine bleeding (DUB) is defined by Blaustein's Pathology of the Female Genital Tract as an abnormal uterine bleeding in a premenopausal woman resulting from alterations in the normal cyclical changes of the endometrium and without an underlying specific pathological cause such as endometritis, polyps, exogenous hormones, hyperplasia, or carcinoma. ${ }^{11}$ Tissue diagnosis is a must in the diagnosis of DUB especially in perimenopausal and postmenopausal female. ${ }^{12}$ The incidence of DUB is $10 \%$ of women in their reproductive years. ${ }^{13}$ In various studies, histopathological examination of DUB has shown a spectrum of findings ranging from normal endometrium like proliferative and secretory to abnormal findings like disordered proliferative endometrium, hyperplasia, irregular shedding or atrophy of endometrium. ${ }^{14-16}$

The fallopian tube is a common specimen in the laboratory now days. It may be examined alone as salpingectomy or tubal ligation specimen or as a part of complex specimen from hysterectomy and/or oophorectomy operations or as part of tubo-ovarian mass. ${ }^{17}$ Plethora of diseases ranging from salpingitis specially tuberculous salpingitis to cystic lesions to invasive carcinoma are found in tube. As this is a common specimen in the histopathology laboratory, knowledge of the general frequency of these lesions among population can be valuable to the pathologist and gynecologist. It is observed that inflammatory tubal lesions forms the major group followed by ectopic tubal pregnancy which is an important cause of maternal morbidity and mortality. ${ }^{18,19}$

Ovarian neoplastic and non-neoplastic lesions possess a challenge to gynecologist. Some nonneoplastic lesions of the ovary usually present as a pelvic mass and mimic an ovarian neoplasm. Therefore their proper recognition and classification is important to allow appropriate therapy. ${ }^{20}$ The typical common lesions encountered in the ovary are functional or benign cysts and tumors. ${ }^{21}$ Ovarian neoplasms are rare, usually detected at a late stage and are large in size, because of their presentation with mild symptoms. ${ }^{22}$ Histopathology remains the single most important modality for diagnosis of ovarian lesions.

The present study is undertaken to study the diverse histomorphological patterns of uterine lesions, ovarian lesions and the lesions of fallopian tube in this part of region and thus offering a specific diagnosis which is of paramount clinical significance. 


\section{Objective}

This study is undertaken to analyze histopathological lesions of uterus, fallopian tube and ovary in rural population of Maharashtra. To know the incidence of various lesions in female genital tract in rural population of Maharashtra.

\section{Materials and Methods}

The present study was conducted in the Department of Pathology, Indian Institute of Medical Sciences and Research, Warudi Dist. Jalna (MH). This study is conducted retrospectively over period of 1 year from March 2017 to March 2018. 140 specimens including hysterectomy with or without salpingooophorectomy specimen, salpingectomy specimen, oophorectomy specimen were subjected to examination. Patient's clinical data was taken with respect to age, clinical manifestation, USG findings and basis of diagnosis. On receipt of surgical specimen, they were fixed in 10\% neutral buffered formalin for 24-48 hours. Gross examination of uterus, cervix with or without bilateral adnexae was carried out as per protocol. Well circumscribed grey to tan lesions with whorled appearance was considered as leiomyoma and details related to its location and numbers were noted. Adequate sections from cervix, endomyometrium, fallopian tubes and ovaries were taken and representative additional sections from leiomyoma and other abnormal areas were also taken, processed and paraffin embedded. The blocks were made, sectioned and stained with Hematoxyline eosin (H\&E) stain. A detailed microscopic histopathological examination pertaining to endometrial glandular and stromal changes, myometrial, tubal and ovarian findings were noted to arrive at final diagnosis. All findings were cumulatively considered and included for further appropriate diagnosis.

\section{Results}

A total 140 specimen of female genital tract were studied over period of 1 year (Table 1 ). These specimens include simple hysterectomy, hysterectomy with bilateral salpingo-oophorectomy, hysterectomy with unilateral salpingo-oophorectomy, unilateral salpingo-oophorectomy or bilateral salpingooophorectomy specimens. The simple hysterectomy constituted $72.8 \%$ of all specimens and was commonest specimen studied. Only 1 bilateral salpingooophorectomy specimen constituted $0.7 \%$ of all specimens.

Age distribution of patients was also studied. The age group was divided into 10 year interval and most patient fall into 40-49 year age group. This group formed $49.3 \%$ of all patients while 50-59 year age group was second most common age group with 20 patients $(14.3 \%)$. The youngest patient was 19 years and oldest was 73 years (Table 2).
Since the study included entire genital tract, the clinical presentation of the patients varied greatly. The most common symptom was abnormal uterine bleeding (50\% cases) followed by abdominal pain ( $28.6 \%$ cases). In $25 \%$ cases, abnormal uterine bleeding was associated with abdominal pain. Of 36 cases of prolapse, 35 complained of something coming out per vagina $(27.9 \%)$ and 1 patient complained of retention of urine $(0.7 \%)$.

The lesions were classified into uterine, endometrial, cervical, tubal and ovarian lesions. Out of total 140 cases, we processed 125 cases of hysterectomy $(89.3 \%)$. These 125 cases showed leiomyoma and adenomyosis as uterine pathology. The leiomyoma were sub classified into sub mucosal, intramural, subserosal or multiple locations. Out of 125 cases, 51 cases $(36.4 \%)$ showed leiomyoma as pathology. The most common leiomyoma was intramural (40 cases) followed by sub mucosal (10 cases). In 6 cases, leiomyoma was present in multiple locations (4.3\%). Grossly, leiomyoma were well circumscribed masses showing solid whorled cut section. Microscopically, it showed well circumscribed tumors consisting of oval to spindle shaped cells having elongated blunt ended nuclei and moderate amount of eosinophilic cytoplasm arranged in interlacing fascicles and bundles (Fig. 1). Some leiomyoma showed secondary changes like hyaline degeneration and myxoid degeneration. If the endometrial glands and stroma are seen embedded beyond one low power field from endomyometrial junction, then it was considered as adenomyosis. Grossly, uterus showed trabeculated myometrium with increased average myometrial thickness. Microscopically deeper myometrium showed islands of endometrial glands and stroma surrounded by hyperplastic smooth muscle bundles. 33 cases of adenomyosis were noted which constituted $23.6 \%$ of total hysterectomy specimens. In short, out of 125 hysterectomy cases, 84 cases had uterine pathology $(67.2 \%)$.

125 cases of hysterectomy revealed 125 endometrial diagnoses (Table 5). In endometrium, most common findings were proliferative phase endometrium 47 cases $(37.6 \%)$, atrophic endometrium 40 cases $(32 \%)$ and secretory phase endometrium 26 cases $(20.8 \%)$. In 7 cases, endometrium showed presence of polyp (5.6\%). The polyps are pedunculated or non pedunculated benign proliferations in endometrial cavity which may mimic carcinoma due to bleeding caused by them. Grossly, polypoid masses ranging from $1 \mathrm{~cm}$ to $6 \mathrm{~cm}$ in diameter were noted in endometrial cavity with dilatation of endometrial lumen. Those diagnosed as Leiomyomatous polyp were not included in this category but were included under sub mucous leiomyoma. Microscopically they showed polypoid mass lined by flattened surface endometrium. The core of polyp showed endometrial glands and edematous stroma along with many thick walled blood 
vessels. Sparse mononuclear cell infiltration is also seen in many polyps. 7 cases showed simple endometrial hyperplasia (5.6\%). Grossly it appears as thickened endometrium (Lusch endometrium). Microscopically it showed back to back endometrial glands with dense compact stroma, increased glands to stroma ratio and gland in gland appearance (Fig. 2). 3 cases (2.4\%) of abnormal uterine bleeding showed disordered proliferative endometrium on microscopy. Few glands appeared in proliferative phase while few showed irregular, dilated glands filled with secretions in lumen (Fig. 3). 1 case $(0.8 \%)$ was diagnosed as endometrial carcinoma in elderly postmenopausal women complaining of postmenopausal bleeding. Grossly, endometrium was thickened. Microscopically endometrial glands were seen with cytological and architectural dysplasia and invasion. Papillary fronds lined by columnar cells having hyperchromatic nuclei and eosinophilic cytoplasm were seen (Fig. 4). In 1 case, endometrium was obliterated by extension of cervical squamous cell carcinoma.

Chronic cervicitis was found in 96 out of 125 hysterectomy cases $(76.8 \%)$. Chronic cervicitis was found overlapping with other lesions of cervix. Other than cervicitis, the cervical pathology was found commonly in cases of uterus with prolapse. In prolapse uterus, cervix is seen as hypertrophic grossly and microscopic finding include hyperkeratosis, acanthosis, squamous metaplasia and chronic cervicitis. The prolapse uterus was frequently associated with bulky uterus or adenomyosis. The cervical changes consistent with prolapse were found in 35 cases $(28 \%)$. 10 cases of cervical polyp were seen which constituted $8 \%$ of hysterectomy cases. It is not uncommon to find invasive cervical carcinoma or In situ carcinoma in hysterectomy cases. We found 4 cases with either invasive carcinoma or In situ carcinoma in 125 cases $(3.2 \%)$.

In fallopian tube, the most common lesion was pyosalpinx (6 cases/15.8\%). In these cases, the fallopian tube was seen dilated with thinned out wall and lumen was filled with pus material (Fig. 5). 2 cases of hematosalpinx $(5.7 \%)$ and 1 case each of ectopic gestation $(2.6 \%)$ and xanthogranulomatous salpingitis $(2.6 \%)$ were seen (Fig. 6). In ectopic gestation, many chorionic villi with decidual tissue and fetal parts were noted in fallopian tube.

The most common lesion in ovary was cystic lesions (Table 8). These include simple cysts $(26.3 \%)$, corpus luteum cyst $(2.6 \%)$, chocolate cyst $(5.3 \%)$, cystic teratoma $(7.9 \%)$ and cyst adenomas $(21.1 \%)$. The simple cysts are lined by single layer of flattened cuboidal epithelium. These cysts may be of mesonephric or paramesonephric origin but their differentiation is of no clinical significance. The corpus luteum cyst is is $>3 \mathrm{~cm}$ in size and is lined by inner granulosa cells and outer layer of theca cells. The chocolate cyst of ovary is actually endometriosis in ovary. There is cyst formation due to accumulation of shedded endometrial tissue from endometriotic glands which appear as chocolaty thick fluid. The cyst adenomas are benign cystic tumors of ovary lined by serous or mucinous columnar epithelium. Of total 38 ovarian specimens, $22(57.9 \%)$ were cystic including non neoplastic and neoplastic. Simple serous cysts was the commonest cystic lesion as well as commonest of all ovarian lesions $(26.3 \%)$ followed by 6 cases of serous cystadenoma $(15.8 \%)$. Out of total $5(13.2 \%)$ cases of Teratoma, $2(5.3 \%)$ were monodermal and 3 (7.9\%) were mature cystic teratoma. The torsion of ovary is usually present with acute abdomen in young patients. We diagnosed $2(5.3 \%)$ cases of torsion of ovary. The gross examination revealed ovary with almost normal size, blackish discoloration of external surface and cut surface showing hemorrhages. Microscopically it showed extensive hemorrhagic necrosis along with dense inflammation and congested and dilated blood vessels. 1 case of benign Brenner tumor of ovary was also noted (Fig. 8)

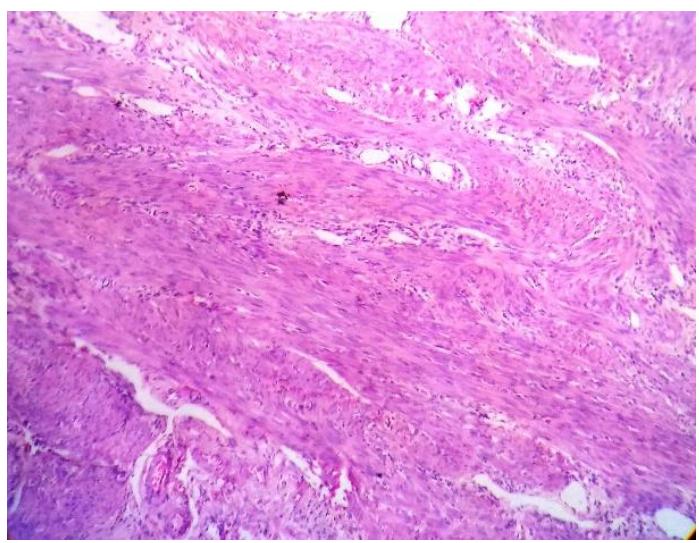

Fig. 1

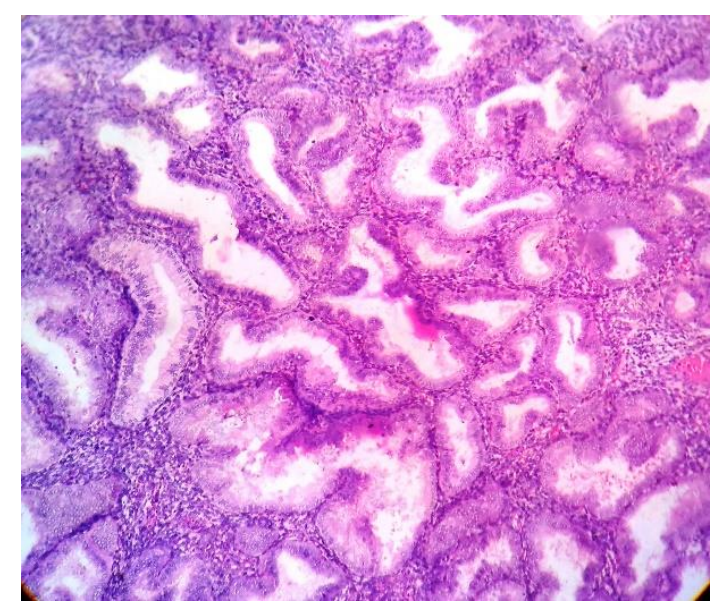

Fig. 2 


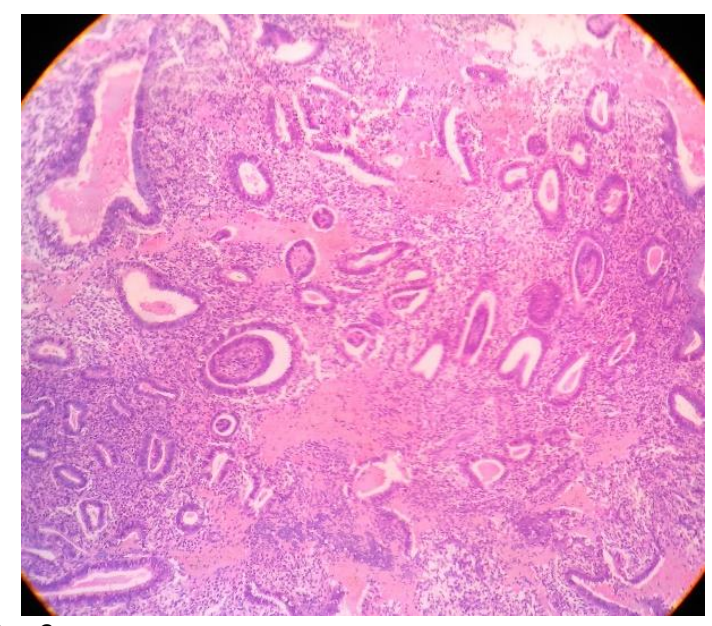

Fig. 3

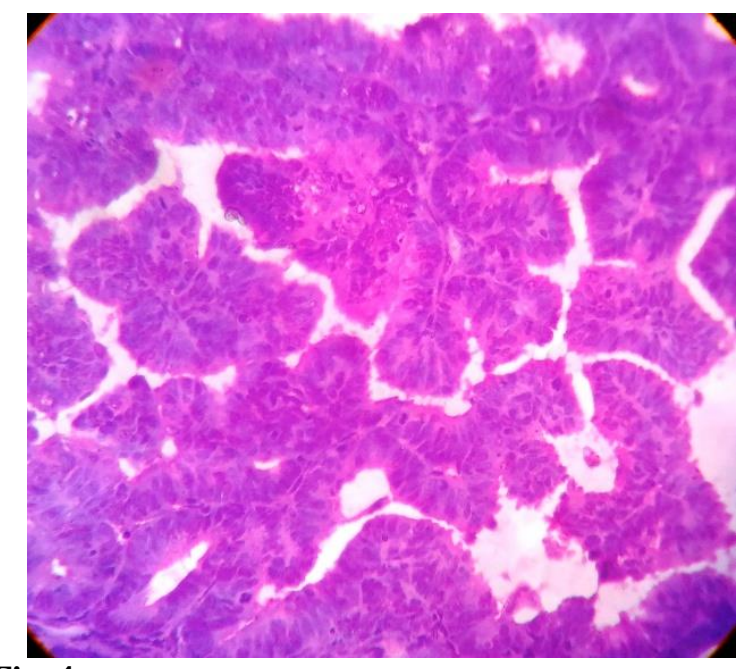

Fig. 4

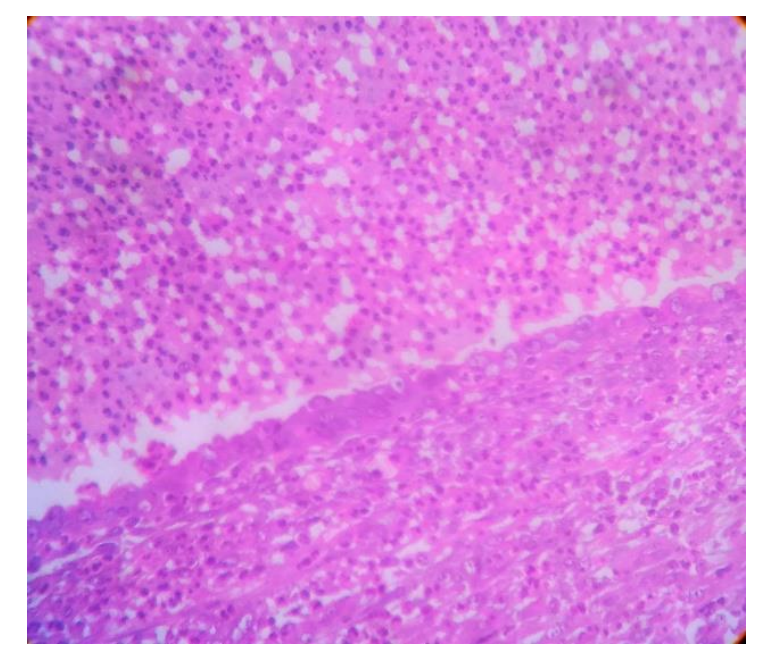

Fig. 5

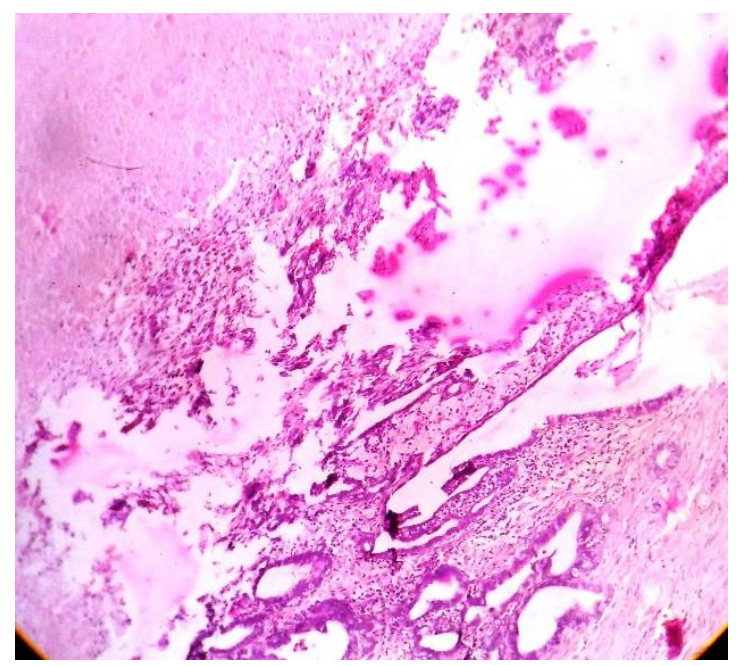

Fig. 6

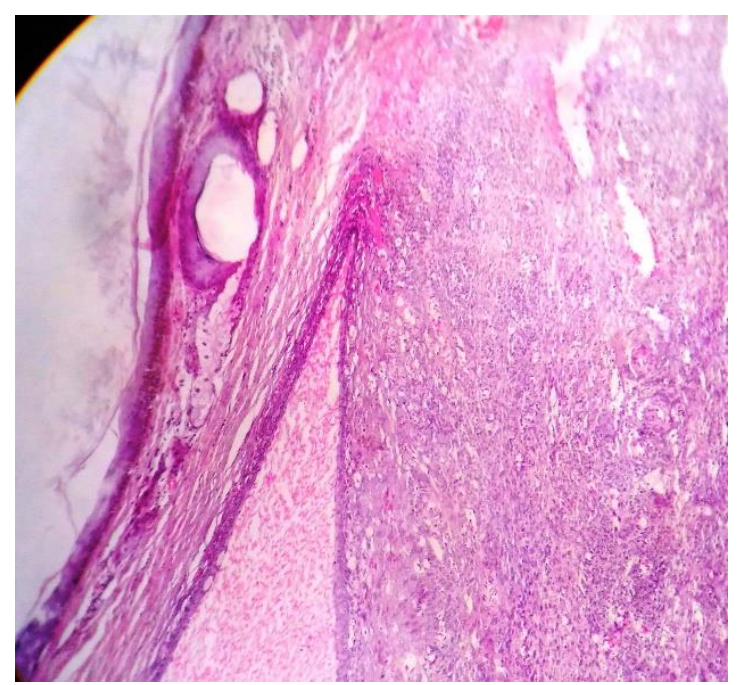

Fig. 7

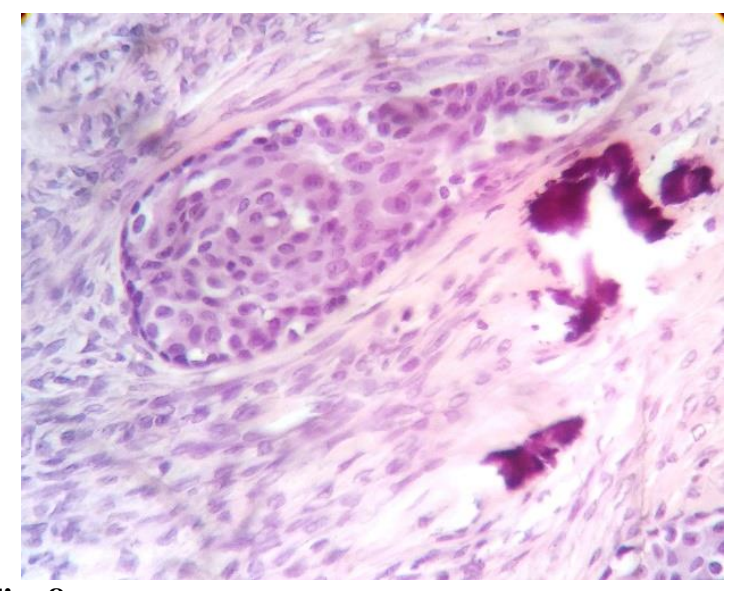

Fig. 8 
Table 1: Type of specimens

\begin{tabular}{|l|c|c|c|}
\hline S. No. & Type of Specimen & Number & Percent \\
\hline 1 & Simple hysterectomy & 102 & 72.8 \\
\hline 2 & Hysterectomy with one sided salpingo-oophorectomy & 12 & 8.6 \\
\hline 3 & hysterectomy with both sided salpingo-oophorectomy & 11 & 7.9 \\
\hline 4 & One sided salpingo-oophorectomy & 14 & 10 \\
\hline 5 & Both sided salpingo-oophorectomy & 1 & 0.7 \\
\hline & Total & 140 & 100 \\
\hline
\end{tabular}

Table 2: Age wise distribution

\begin{tabular}{|l|c|c|c|}
\hline S. No. & Age in years & Number & Percentage \\
\hline 1 & $20-29$ & 8 & 5.7 \\
\hline 2 & $30-39$ & 29 & 2.7 \\
\hline 3 & $40-49$ & 69 & 49.3 \\
\hline 4 & $50-59$ & 20 & 14.3 \\
\hline 5 & $60-69$ & 12 & 8.6 \\
\hline 6 & $>70$ & 2 & 1.4 \\
\hline & Total & 140 & 100 \\
\hline
\end{tabular}

Table 3: Clinical presentation of patients

\begin{tabular}{|l|c|c|c|}
\hline S. No. & Clinical Manifestations & Number & Percentage \\
\hline 1 & Abnormal uterine bleeding & 70 & 50 \\
\hline 2 & Dysmenorrhoea & 39 & 25 \\
\hline 3 & Something coming out per vagina & 35 & 27.9 \\
\hline 4 & Abdominal pain & 40 & 28.6 \\
\hline 5 & Retention of urine & 1 & 0.7 \\
\hline
\end{tabular}

Table 4: Histopathology of uterine lesions

\begin{tabular}{|l|c|c|c|}
\hline S. No. & Diagnosis & Number & Percentage \\
\hline 1 & Leiomyoma & 51 & 36.4 \\
\hline & Intramural & 40 & 28.6 \\
\hline & Subserosal & 8 & 5.7 \\
\hline & Submucosal & 10 & 7.1 \\
\hline & Multiple location & 6 & 4.3 \\
\hline 2 & Adenomyosis & 33 & 23.6 \\
\hline \multicolumn{2}{|c|}{ Total } & $84 / 125$ & 67.2 \\
\hline
\end{tabular}

Table 5: Histopathology of endometrium

\begin{tabular}{|l|c|c|c|}
\hline S. No. & Diagnosis & Number & Percentage \\
\hline 1 & Proliferative phase & 47 & 37.6 \\
\hline 2 & Secretory phase & 26 & 20.8 \\
\hline 3 & Disordered prolifration & 3 & 2.4 \\
\hline 4 & Simple endometrial hyperplasia & 7 & 5.6 \\
\hline 5 & Atrophic endometrium & 33 & 26.4 \\
\hline 6 & Endometrial polyp & 7 & 5.6 \\
\hline 7 & Endometrial carcinoma & 1 & 0.8 \\
\hline 8 & Extension of cervical squamous cell carcinoma & 1 & 0.8 \\
\hline \multicolumn{2}{|c|}{ Total } & 125 & 100 \\
\hline
\end{tabular}

Table 6: Histopathology of cervix

\begin{tabular}{|l|c|c|c|}
\hline S. No. & Diagnosis & Number & Percentage \\
\hline 1 & Consistent with prolapse & 35 & 28 \\
\hline 2 & Carcinoma cervix/CIN & 4 & 3.2 \\
\hline 3 & Cervical polyp & 10 & 8 \\
\hline 4 & Squamous metaplasia & 30 & 24 \\
\hline 5 & Chronic cervicitis & 96 & 76.8 \\
\hline
\end{tabular}


Table 7: Histopathology of fallopian tubes

\begin{tabular}{|l|c|c|c|}
\hline S. No. & Diagnosis & Number & Percentage \\
\hline 1 & Hematosalpinx & 2 & 5.3 \\
\hline 2 & Pyosalpinx & 6 & 15.8 \\
\hline 3 & Ectopic & 1 & 2.6 \\
\hline 4 & Xanthogranulomatous salpingitis & 1 & 2.6 \\
\hline 5 & No specific lesion & 28 & 73.7 \\
\hline \multicolumn{2}{|c|}{ Total } & 38 & 100 \\
\hline
\end{tabular}

Table 8: Histopathology of ovary

\begin{tabular}{|l|c|c|c|}
\hline S. No. & Diagnosis & Number & Percentage \\
\hline 1 & Simple serous cyst & 10 & 26.3 \\
\hline 2 & Hemorrhagic corpus luteal cyst & 1 & 2.6 \\
\hline 3 & Chocolate cyst & 2 & 5.3 \\
\hline 4 & Monodermal teratoma & 2 & 5.3 \\
\hline 5 & Mature cystic teratoma & 3 & 7.9 \\
\hline 6 & Serous cystadenoma & 6 & 15.8 \\
\hline 7 & Mucinous cystadenoma & 2 & 5.3 \\
\hline 8 & Torsion of ovary & 2 & 5.3 \\
\hline 9 & Benign brenner tumor & 1 & 2.6 \\
\hline 10 & No specific lesion & 9 & 23.8 \\
\hline & Total & 38 & 100 \\
\hline
\end{tabular}

Table 9: Comparison with uterine lesions

\begin{tabular}{|c|c|c|}
\hline Study & Leiomyoma & Adenomyosis \\
\hline Bhosale et al $^{26}$ & $55 \%$ & $29.4 \%$ \\
\hline Sobande et $\mathrm{al}^{24}$ & $25.8 \%$ & $22.7 \%$ \\
\hline Ahsan et $\mathrm{al}^{25}$ & $36 \%$ & $30 \%$ \\
\hline Madiha et $\mathrm{al}^{23}$ & $39 \%$ & $19 \%$ \\
\hline${\text { Gupta et } \text { al }^{10}}^{10}$ & $34 \%$ & $10.89 \%$ \\
\hline Our study & $36.4 \%$ & $23.6 \%$ \\
\hline
\end{tabular}

Table 10: Comparison with endometrial lesions

\begin{tabular}{|c|c|c|c|c|c|c|}
\hline Study & $\begin{array}{c}\text { Endometrial } \\
\text { polyp }\end{array}$ & $\begin{array}{c}\text { Endometrial } \\
\text { hyperplasia }\end{array}$ & $\begin{array}{c}\text { Endometrial } \\
\text { carcinoma }\end{array}$ & $\begin{array}{c}\text { Disordered } \\
\text { Proliferative } \\
\text { Endometrium }\end{array}$ & $\begin{array}{c}\text { Proliferative/ } \\
\text { Secretory/ } \\
\text { Atrophic }\end{array}$ & Other \\
\hline Nayak et $\mathrm{a}^{35}$ & $0.6 \%$ & $27.5 \%$ & $1.2 \%$ & - & $66.3 \%$ & $4.3 \%$ \\
\hline Gowri et al ${ }^{34}$ & $4.2 \%$ & $22.8 \%$ & - & - & $73 \%$ & - \\
\hline Dayal S et al ${ }^{32}$ & $1.8 \%$ & $5 \%$ & & & $86 \%$ & $2.5 \%$ \\
\hline $\begin{array}{l}\text { Kakkar M et } \\
\mathrm{al}^{33}\end{array}$ & - & $9.6 \%$ & - & $4.7 \%$ & $82.1 \%$ & $3.6 \%$ \\
\hline Our study & $5.6 \%$ & $5.6 \%$ & $0.8 \%$ & $2.4 \%$ & $84.8 \%$ & $0.8 \%$ \\
\hline
\end{tabular}

Table 11: Comparison with ovarian lesions

\begin{tabular}{|c|c|c|c|c|c|c|}
\hline study & $\begin{array}{c}\text { Benign cysts } \\
\text { (Non neoplastic) }\end{array}$ & cystadenomas & teratoma & torsion & $\begin{array}{c}\text { Benign } \\
\text { Brenner }\end{array}$ & Malignant \\
\hline Prakash et al ${ }^{37}$ & $41 \%$ & $49.3 \%$ & $3.5 \%$ & $2.2 \%$ & - & $1.7 \%$ \\
\hline Sawant et al ${ }^{36}$ & $77 \%$ & $17.5 \%$ & $2.1 \%$ & - & - & $5.6 \%$ \\
\hline Our study & $34.2 \%$ & $21.1 \%$ & $13.2 \%$ & $5.3 \%$ & $2.6 \%$ & - \\
\hline
\end{tabular}

\section{Discussion}

Hysterectomy is commonly performed gynecological surgery in the world. It can be simple hysterectomy or hysterectomy with removal of one or more adnexae. The decision to remove the organ is very traumatic in patient's point of view and hence must be taken judiciously only after all conservative modalities fail. Charles Clay was the first to perform subtotal and total hysterectomy in Manchester, England in 1843 and 1929 respectively. ${ }^{27,28}$ It is curative for most of benign and neoplastic lesions of uterus. Benign conditions like leiomyoma, DUB, adenomyosis, PID, endometriosis 
and uterine prolapse account for major hysterectomies and rest for malignancy. ${ }^{29,30}$ Leiomyoma are benign neoplasm composed of smooth muscle with variable amount of connective tissue. ${ }^{3-5}$ Leiomyoma are commonly seen in the women of reproductive age. ${ }^{3-5,9}$ In present study, most of the patients with leiomyoma were in reproductive age group (57.7\%) similar to studies by Begum $\mathrm{S}$ et $\mathrm{al}^{7}$ whereas in contrast Hafiz $\mathrm{R}$ et $\mathrm{al}^{31}$ observed that affected females were a decade lesser 20-40 years of age possibly since they included only menorrhagic patients with fibroid. Our study found that out of total 125 hysterectomy cases, $36 . \%$ cases had leiomyoma. Similar findings were observed in study by Ahsan et al, ${ }^{25}$ Gupta et $\mathrm{al}^{10}$ and Madiha et al. ${ }^{23}$ Few studies found higher incidence like Bhosale et $\mathrm{al}^{26}$ $(55 \%)$ while some studies found lower incidence eg. Sobande et $\mathrm{al}^{24}(25.8 \% \%)$. In our study, adenomyosis was found in $23.65 \%$ cases similar to Sobande et $\mathrm{al}^{24}$ (22.7\%) and Bhosale et $\mathrm{al}^{26}(29.4 \%)$ [Table 9]. Most cases of prolapse had co-existing adenomyosis. This may be due to bulky uterus stressing upon supportive ligaments of uterus.

In present study, the spectrum of endometrial lesions is shown in Table 5. Most of the endometrium shows proliferative phase (37.6\%) followed by atrophic endometrium (26.4\%). The endometrial polyp was seen in 7 cases (5.6\%). In these lesions, polypoid growth in endometrium was clinically confused for carcinoma. On gross examination, well circumscribed lesions ranging from $1 \mathrm{~cm}$ to $6 \mathrm{~cm}$ were noted in endometrial cavity. The cut section was brownish in most cases. On microscopy, polypoid lesion was lined on all sides by flattened surface endometrium. The core of polyp shows endometrial glands and stroma with many thick walled vessels. Gowri et al ${ }^{34}$ found $4.2 \%$ incidence of endometrial polyps in a large study of 259 hysterectomy specimens. Other studies like Nayak et $\mathrm{al}^{35}(0.6 \%)$ and Dayal et $\mathrm{al}^{32}(1.8 \%)$ showed lower incidence. The endometrial hyperplasia was seen in 7 cases $(5.6 \%)$ which is comparable to study by Dayal et $\mathrm{al}^{32}(5 \%)$ but did not match with other studies like Nayak et $\mathrm{al}^{35}(27.5 \%)$ and Gowri et $\mathrm{al}^{34}(22.8 \%)$.

There were 38 ovarian specimens either unilateral or bilateral included in study. The most common lesion was benign non neoplastic cystic lesion $(34.2 \%)$. These include simple cysts, corpus luteum cyst, chocolate cyst. A study by Prakash et $\mathrm{al}^{37}$ found incidence of $41 \%$ for these lesions while Sawant et $\mathrm{al}^{36}$ found incidence of $77 \%$ for these lesions. The incidence of teratoma did not match with any study. The cystadenomas are benign neoplastic lesions of the ovary. They include mucinous and serous cystadenoma and cystadenofibromas. We found incidence of $21.1 \%$ as against $17.5 \%$ by Sawant et al. ${ }^{36}$

Out of 38 fallopian tubes, 28 did not have any pathology which comprises $73.7 \%$. A study by Bagwan et $\mathrm{al}^{38}$ found no any pathology in $66.5 \%$ cases and pathology in $33.5 \%$ cases which matches with our study. Most of the lesions in both studies were inflammatory. Identification of inflammatory pathology is important because it is one of the causes for infertility. Simillarly, ectopic gestation is important cause of maternal mortality. We found incidence of $2.6 \%$ for ectopic gestation in our scenario while Bagwan et $\mathrm{a}^{38}$ found incidence of $11.3 \%$ for the same.

\section{Conclusion}

Female genital tract is source of various lesions and histopathology remains the primary diagnostic modality. Leiomyoma and adenomyosis remain the leading cause of morbidity in uterus among rural population of Maharashtra. Lesions of ovary and fallopian tube are equally important and should undergo histopathological evaluation. Frequency of malignant lesions is low in rural population.

\section{References}

1. Vessey MP, Villard-Mackintosh L, McPherson K, Coulter A, Yeats D. The epidemiology of hysterectomy: findings in a large cohort study. Br J Obstet Gynecol. 1992;99:402-7.

2. Clayton RD. Hysterectomy. Best practice and Research. Clinical Obstet Gynecol. 2006;20:73-87.

3. Crum C P. Body of uterus and Endometrium. In: Kumar V, Abbas A K, Fausto N, Eds. Robbins and Cotran Pathologic Basis of Disease. 7th ed. Philadelphia: Saunders, 2004:1089-90.

4. Silverberg S G, Tabbara S O. The uterine corpus. In: Silverberg S G, Delellis R A, Frable W J, Eds. Principles and Practice of Surgical Pathology and Cytopathology. Vol 3 (3rd edition). New York: Churchill Livingstone, 1997:2459-516.

5. Ackerman, Gull B, Karlsson B, Milsom I, Granberg S. Factors associated with endometrial thickness and uterine size in random sample of postmenopausal women. Am J Obstet Gynecol. 2001;185(2):386-91.

6. Witherspoon T J. The interrelationship between ovarian follicle cysts, hyperplasia of the endometrium and fibromyomata. Surg Gynecol Obstet. 1933;56:1026-35.

7. Rein MS, Barbieri RL, Friedman AJ. Progesterone: A critical role in pathogenesis of uterine myomas. Am J Obst Gynecol. 1995;172(1)14-8.

8. Begum S, Khan S. Audit of leiomyoma uterus at Khyber Teaching Hospital, Peshawar. J Ayub Med Coll. 2004;16(2):46-9.

9. Frances Jr H. Abdominal myomectomy as a treatment for symptomatic uterine fibroids. Obstetrics and gynecology clinics North-America. 1995;22(4):781-9.

10. G. Gupta, D.S. Kotasthane, V.D. Kotasthane: Hysterectomy: A Clinico-Pathological Correlation Of 500 Cases. The Internet Journal of Gynecology and Obstetrics. 2010 Volume 14 Number 1. DOI: 10.5580/141b.

11. Robert J Kurman. Blaustein's Pathology of the Female Genital Tract. Springer. $5^{\text {th }}$ Edition.2004.1391p.

12. Livingstone M, Fraser IS. Mechanism of abnormal uterine bleeding. Hum Reprod Update 2002;8:60-7.

13. Lobo, Rogerio A. "Chapter 37 - Abnormal Uterine Bleeding: Ovulatory and Anovaulatory Dysfunctional Uterine Bleeding, Management of Acute and Chronic Excessive Bleeding." Comprehensive Gynecology. Eds. V. L. Katz, et al. 5th ed. Mosby Elsevier, 2007. 
14. Davey DA. Dysfunctional uterine bleeding. In: Whitfield CR editor: Dewhurst's textbook of Obstetrics and Gynecology for postgraduates. 4th ed. London: Blackwell science; 1995.pp 624-45.

15. Mills SE, Carter D, Greenson JK, Reuter VE, Stoler MH, editor. The uterine corpus. Sternberg's Diagnostic Surgical Pathology, 5th ed. Vol.2. Philadelphia: Lippincort Williams \&Willkins;2010.pp 2190-213.

16. Khadilkar S. Endometrium in DUB. In: Purandare CN editor: Dysfunctional uterine bleeding -An update. New Delhi: JAYPEE;2004.pp 271-41.

17. Gon S, Basu A, Majumdar B, Das TK, Sengupta M, Ghosh D. Spectrum of histopathological lesions in the fallopian tubes. J Pathol Nepal. 2013;3:356 -60.

18. Bagwan IN, Harke AB, Malpani MR, Deshmukh SD. Histopathological spectrum of lesions encountered in the fallopian tube. J Obstet Gynecol Ind. 2004 JulAug;54(4):379-82.

19. K SS, K AS. Clinical study of ectopic pregnancies in a tertiary care hospital of Mangalore. Innov J Med Health Sci. 2014 Jan-Feb;4:305-9.

20. Srikanth S, Anandam G. Bilateral dermoid cyst of ovary. Med J DY Patil Univ. 2014;7:4923. Available from: https:// doi.org/10.4103/0975-2870.135281

21. Ellenson LH, Pirog EC. Ovaries. In: Robbins and CotranPathologic Basis of Disease. South Asia Edition. New Delhi: Reed Elsevier India. 2014: 1022.

22. Bhattarcharya MM, Shinde SD, Purandare VN. A clinicopathological analysis of 270 ovarian tumors. $J$ Postgrad Med. 1980;26:103-7.

23. Madiha Sajjad, Samina Iltaf, Shazia Qayyum. Pathological findings in hysterectomy specimens of patients presenting with menorrhagia in different age groups. Ann Pak Inst Med Sci. 2011;7(3):160-162.

24. Sobande AA, Eskander M, Archibong EI, Damole IO. Elective hysterectomy: A clinicopathological review from Abha catchment area of Saudi Arabia. West Afr J Med. 2005;24:31-5.

25. S.Ahsen, Naeem A, Ahsan A.A. A case note analysis of hysterectomy performed for non-neoplastic indications at Liaqat National Hospital, Karachi. J Pak Med Ass. 2001;51(10):346 -9.

26. Archana B, Michelle F. Evaluation and Histopathological Correlation of Abnormal Uterine Bleeding in Perimenopausal Women Bombay Hospital Journal. 2010;52(1): 69-72.

27. John A, Rock MD, Jhon D, Thompson MD; Telinds's Operative Gynaecology. 1st Edition Lippincott- Raven place.
28. Nausheen F, Iqbal J, Bhatti FA, Khan AT, Sheikh S. Hysterectomy: The patient's perspective. Annals Gynecol. 2004;10:339-41.

29. Gupta S, Manyonda I. Hysterectomy for benign gynecological diseases. Current Obstet Gynaecol. 2006; 16:147- 53.

30. Rani S. V. R, Thomas S. Leiomyoma, a major cause of abnormal uterine bleeding. J of Evolution of Medical and Dental Sciences. 2013;2:2626-30.

31. Hafiz R, Ali M, Ahmed M. Fibroid as a causative factor in menorrhagia and its management. DHQ Hospital Rajan Pur, Nishtar Hospital Multan. J Med Res. 2003;42(3):906.

32. Dayal S, Nagrath A. Clinicopathological correlation of endometrial, myometrial and ovarian pathologies with secondary changes in leiomyoma. Journal of Pathology of Nepal. (2016) Vol. 6, 937-941

33. Kakkar M, Gupta A, Koul K. Patterns of Endometrial Histopathology in Patients of Dysfunctional Uterine Bleeding (DUB). International Journal of Science and Research (IJSR) ISSN (Online): 2017;6(6):2751-2754

34. Gowri M, Mala G, Murthy S, Nayak V. Clinicopathological study of uterine leiomyomas in hysterectomy specimens. Journal of Evolution of Medical and Dental Sciences. 2013;2(46):9002-9009.

35. Nayak A, Hazra K, Jain M. Clinico-pathological evaluation of dysfunctional uterine bleeding. International Journal of Contemporary Medical Research. 2017;4(4):920-924.

36. Sawant A Mahajan S. Histopathological Study of Ovarian Lesions at a Tertiary Health Care Institute. MVP Journal of Medical Sciences; 2017;4(1):26-29.

37. Prakash A et al. Histopathological study of ovarian lesions in a tertiary care center in Hyderabad, India: a retrospective five-year study. Int $J A d v \mathrm{Med}$. 2017;4(3):745-749

38. Bagwan et al. Histopathological Study of Spectrum of Lesions Encountered in the Fallopian Tube. J Obstet Gynecol Ind. 2004;54(4):379-382.

How to cite this article: Patil AS, Jadhav RM., Narkhede P. Histopathological study of lesions of female genital tract in rural Maharashtra. J Diagn Pathol Oncol. 2018;4(3):160-167. 